\title{
The Role of Thyrotropin-Releasing Hormone Stimulation Test in Management of Hyperthyrotropinemia in Infants
}

\author{
Ayça Altıncık, Korcan Demir, Gönül Çatlı, Ayhan Abacı, Ece Böber \\ Dokuz Eylül University Faculty of Medicine, Department of Pediatrics, Division of Pediatric Endocrinology, Izmir, Turkey
}

\begin{abstract}
Objective: Hyperthyrotropinemia, which can be either a permanent or a transient state, is an asymptomatic condition and there is a controversy in management and long-term consequences. The aim of this study was to evaluate the results of thyrotropin-releasing hormone (TRH) test in infants with hyperthyrotropinemia.

Methods: Data of the patients who underwent a TRH test for mildly elevated thyroid-stimulating hormone (TSH) levels between 2004 and 2011 in a single academic pediatric endocrinology unit were retrospectively reviewed from the case files.

Results: Twenty infants (13 female, 7 male) with the median (range) age of 33 days (25-50) were enrolled into the study. The median basal TSH was $7.0 \mathrm{mlU} / \mathrm{L}(4.9-8.9)$ and free thyroxine level was $1.4 \mathrm{ng} / \mathrm{mL}(1.2-1.6)$ at the time of the TRH test. Thyroid ultrasonography was performed to 10 of the cases, and one of them had thyroid hypoplasia. TRH test revealed normal results in four infants, while sixteen infants had exaggerated response suggestive of primary hypothyroidism. The median follow-up period was 3.5 years (2.33.7). Therapy was discontinued in seven cases ( 2 had normal TRH response, 5 had exaggerated response) with the median age of 3.2 years (2.5-4). Of these seven infants, three had an elevated TSH on follow-up and L-thyroxine was restarted. All of the infants, in whom therapy was restarted, had exaggerated response to TRH.

Conclusion: TRH test response could be a useful diagnostic test to evaluate the persistence of the disease during the infantile age period.

Key words: Hyperthyrotropinemia, hypothyroidism, thyrotropin-releasing hormone
\end{abstract}

Conflict of interest: None declared

Received: 10.03 .2015

Accepted: 27.04 .2015

\section{Introduction}

Congenital hypothyroidism $(\mathrm{CH})$ is one of the most common preventable causes of mental retardation. Early detection and treatment of $\mathrm{CH}$ prevents neurological deficits. Infants with free thyroxine $\left(\mathrm{fT}_{4}\right.$ ) concentration below the norm for age and/or a venous thyroid-stimulating hormone (TSH) concentration persistently $>20 \mathrm{mU} / \mathrm{L}$ must be treated with L-thyroxine immediately (1). Since the introduction of screening programs for $\mathrm{CH}$, transient or mild disturbances of thyroid function, especially transient hyperthyrotropinemia, have been reported with variable frequencies $(2,3,4)$. If the venous TSH concentration is $\geq 6$ to $20 \mathrm{mU} / \mathrm{L}$ beyond 21 days in a healthy infant with a normal $\mathrm{fT}_{4}$ concentration, there is no consensus on the investigation and treatment of these newborns (1).

Nationwide capillary TSH screening is being conducted in Turkey since 2006 and all newborns with TSH values higher than 15 and $5.5 \mathrm{mU} / \mathrm{L}$ in the first and second specimens, respectively, are directed to pediatric endocrinologists. Both serum TSH and $\mathrm{fT}_{4}$ measurements are evaluated at recall examination (5). In most cases, diagnosis of hypothyroidism is not difficult to establish given the low T4 with elevated TSH values. However, some of the newborns may have borderline results and have persistent hyperthyrotropinemia with normal or borderline serum T4 levels during infancy (6).

The aims of the present study were i) to evaluate the thyrotropin response to thyrotropin-releasing hormone (TRH) test in infants with mildly elevated TSH and normalborderline $\mathrm{fT}_{4}$ levels, ii) to evaluate the clinical usefulness of the TRH test in infants, and iii) to determine the natural course of hyperthyrotropinemia. 


\section{Methods}

We retrospectively reviewed the data of infants who were evaluated in our center in the years between 2004 and 2011 and in whom a TRH test was carried out because of mildly elevated TSH values with normal and/or borderline $\mathrm{fT}_{4}$ levels. Exclusion criteria were having multiple pituitary hormone deficiency or central hypothyroidism. Accordingly, infants with low $\mathrm{fT}_{4}$ levels with inappropriately normal or low TSH levels and a TRH test with impaired TSH release, accepted as a TSH increase of less than $5 \mathrm{ml} / \mathrm{L}$ (7), were excluded. Incomplete $\mathrm{TRH}$ test results because of haemolysed or inadequate blood samples, underlying severe systemic disease, preterm birth $(<36$ gestation weeks) and clinical follow-up time shorter than a year were also reasons for exclusion. Data including birth weight, gestation week, family history, age at the time of the TRH test, laboratory and radiological findings during follow-up were recorded from the case files.

A TRH stimulation test was performed after confirming that at least two TSH levels were between 5-20 mlU/L. A baseline blood sample was collected before TRH injection for $\mathrm{fT}_{4}, \mathrm{TSH}$, and prolactin (PRL) measurement. TRH (Ferring Pharmaceuticals Ltd, Kiel, Germany; $7 \mu \mathrm{cg} / \mathrm{kg}$, maximum $200 \mathrm{mg}$ ) was administered as an intravenous bolus. Plasma TSH and PRL were measured 15, 45 and 60 minutes after administration of TRH. A peak TSH value higher than 35 $\mathrm{mIU} / \mathrm{L}$ after $\mathrm{TRH}$ stimulation was accepted as an exaggerated response suggestive of primary hypothyroidism and those below $35 \mathrm{mIU} / \mathrm{L}$ were considered normal (8).

All hormone assays were performed in the endocrine laboratory of the Dokuz Eylül University Faculty of Medicine. TSH and PRL were measured by immunochemiluminometric assay (Immulite 2500 immunoassay, Siemens Diagnostic Products Corporation). Free T4 was measured by RIA.

\section{Statistical Analysis}

SPSS 13.0 (SPSS Inc., Chicago; IL) was used. MannWhitney U-test (non-parametric data) was used for comparisons of numerical variables. Chi-square or Fisher's exact test were used to compare categorical variables. For all analyses, a twotailed $p<0.05$ was considered statistically significant. Results were expressed as $n(\%)$ or median (25th-75th percentile).

\section{Results}

Of the 45 patients who underwent a TRH test, 20 infants (13 female, 7 male) fulfilled the inclusion criteria (Figure 1). There was no history of maternal ingestion of thyroid hormones or goitrogens. The parents of two infants were consanguineous. In four cases, family history revealed hypothyroidism in grandmothers and aunts. Seven infants had nonsensical clinical signs (prolonged jaundice, decreased weight gain, or constipation).
Median age of the infants at the time of $\mathrm{TRH}$ testing was 33 days (25-50 days). Four infants had a normal (group 1) and sixteen infants had an exaggerated response to TRH (group 2) (Figure 1). Clinical and laboratory data of the groups are given in Tables 1 and 2.

Bone age was determined in seven cases. One infant with exaggerated TRH test had delayed bone age (absence of distal femoral epiphyses), others were normal. Thyroid volume and morphology were examined by ultrasound in 10 cases, and one of the children had thyroid hypoplasia (thyroid volume was 0.15 $\mathrm{mL}=-2.89$ SDS according to reference values (9).

All patients except one with normal TRH test response received L-thyroxine treatment (Figure 1). The median follow-up period was 3.5 years (2.3-3.7 years). The median age of infants at the last clinic visit was 3.8 years (3.3-4.5 years).

Treatment was discontinued in seven cases (two had a normal $\mathrm{TRH}$ response, five an exaggerated response) at a median (range) age of 3.2 years (2.5-4 years) (Figure 1). The L-thyroxine dose was $0.9 \mu \mathrm{g} / \mathrm{kg} / \mathrm{d}(0.9-1.5 \mu \mathrm{g} / \mathrm{kg} / \mathrm{d})$, median TSH level $2.2 \mathrm{mIU} / \mathrm{L}$ (2.1-4.2 mlU/L) and median $\mathrm{fT}_{4}$ level was $1.3 \mathrm{ng} / \mathrm{mL}$ (1.1-2.2) at the time of discontinuation. Of these 7 infants, 3 had an elevated TSH on follow-up and L-thyroxine was restarted (Figure 1). All of the infants in whom treatment was restarted had shown an exaggerated response to $\mathrm{TRH}$. In the remaining 4 infants in whom treatment was discontinued, median follow-up period after discontinuation was 1.8 years (0.4-3.8), and the median $\mathrm{TSH}$ and $\mathrm{fT}_{4}$ levels at the last clinic visit were $2.1 \mathrm{mIU} / \mathrm{L}$ (1.6-2.7) and $1.4 \mathrm{ng} / \mathrm{mL}$ (1.1-3.9), respectively. Comparison of the clinical and laboratory data of the infants are given in Table 3.

In twelve infants (one with normal, eleven with exaggerated $\mathrm{TRH}$ response), discontinuation had never been tried (Figure 1).

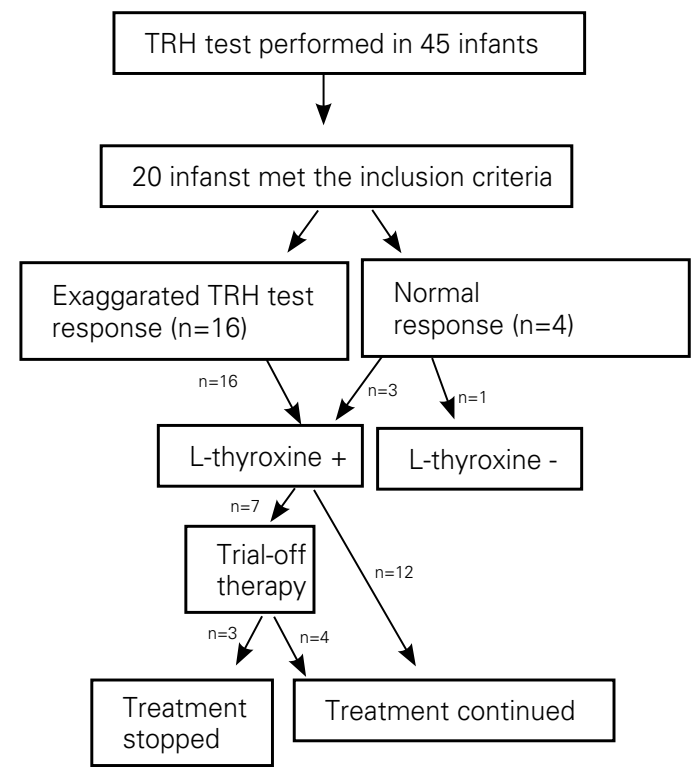

Figure 1. Scheme of the study group 
The median follow-up period was 3.8 years (2.8-3.9), and the median L-thyroxine dose was $1.9 \mu \mathrm{g} / \mathrm{kg} / \mathrm{d}$ (0.9-3.0 $\mu \mathrm{g} /$ $\mathrm{kg} / \mathrm{d})$. Of these 12 infants, one had thyroid dysgenesis, eight had occasions of high TSH levels while under L-thyroxine therapy, and three were younger than 3 years old.

\section{Discussion}

Rapaport et al (8) performed a TRH test to 68 infants with subclinical hypothyroidism (SH). Peak TSH values of $35 \mathrm{mIU} / \mathrm{L}$ or less were considered as normal, and peak TSH values above $35 \mathrm{mIU} / \mathrm{L}$ were considered as hyperresponsive. L-thyroxine replacement was given to all hyperresponsive infants. During long-term follow-up, all infants with normal $\mathrm{TRH}$ test results have remained euthyroid. Thirteen of 40 hyperresponsive infants had evidence of thyroid dysfunction in follow-up (elevation of TSH during or after discontinuing treatment) and treatment had to be continued or re-started. The authors have concluded that the TSH response to TRH is a useful tool for the evaluation of infants with mildly abnormal TSH levels and that infants with TSH levels $>35$ $\mathrm{IU} / \mathrm{mL}$ after TRH are at risk of hypothyroidism. In our study, we were able to discontinue treatment in only 2 of the 16 infants with exaggerated responses. Treatment was discontinued in 2 of the 4 infants with normal TRH test results. Calaciura et al (10) evaluated thyroid functions in 56 newborns with false positive screening results (blood spot $\mathrm{TSH}>20 \mathrm{mU} / \mathrm{L}$, normal serum $\mathrm{fT}_{4}$ with normal or borderline high/normal TSH at recall). Infants with normal TSH levels at recall were considered as group 1 , and those with mildly elevated TSH levels (5-11.7 $\mathrm{mU} / \mathrm{L})$ as group 2. TRH test was carried out in 48 of 56 children. 33\% of group 1 and $59 \%$ of group 2 infants had exaggerated responses. L-T4 treatment was started in infants in group 2 and was stopped 2-3 months before the initiation of the study, at a time when the infants had reached ages 2-3 years. At 2-3 years old, serum TSH levels were found to be higher than the 99.7th percentile of healthy controls in $50 \%$ of the study group.

Table 1. Clinical, laboratory, and auxological parameters of the infants in groups 1 (normal thyrotropin-releasing hormone test result) and 2 (exaggerated thyrotropin-releasing hormone test result)

\begin{tabular}{|c|c|c|c|}
\hline & $\begin{array}{l}\text { TSH peak }>35 \mathrm{mlU} / \mathrm{L} \\
n=16\end{array}$ & $\begin{array}{l}\text { TSH peak } \leq 35 \mathrm{mIU} / \mathrm{L} \\
\mathrm{n}=4\end{array}$ & p-value \\
\hline${ }^{*}$ Gender (female/male) & $10 / 6$ & $3 / 1$ & 0.63 \\
\hline Mean age at date of test (days) & $32(24-50)$ & $34(27-47)$ & 0.31 \\
\hline${ }^{* *}$ L-thyroxine dose $(\mu \mathrm{g} / \mathrm{kg} / \mathrm{d})$ & $2.4(1.6-3.7)$ & $4.6(1.8-7.5)$ & 0.60 \\
\hline §Uncertain clinical symptoms ( $\mathrm{n}$ ) & $7 / 16$ & $0 / 4$ & ND \\
\hline Follow-up duration (years) & $3.5(2.4-3.8)$ & $3.5(2-3.7)$ & 0.5 \\
\hline Height SDS at last visit & $0.4(-0.6-0.9)$ & $-0.9(-1.1-1.9)$ & 0.32 \\
\hline Weight SDS at last visit & $0.3(-0.3-0.5)$ & $0.2(-0.4-1.9)$ & 0.9 \\
\hline \multicolumn{4}{|c|}{$\begin{array}{l}\text { Results are given as median }\left(25^{\text {th }}-75^{\text {th }} \text { percentile) }\right. \\
{ }^{*} \text { Fisher exact test, }{ }^{*} \text { L-thyroxine dose when the infants were } 1 \text { years old, }{ }^{\S} \text { Number of the infants with possible positive clinical symptoms suggestive of hypothyroidism } \\
\text { TSH: thyroid-stimulating hormone, SDS: standard deviation score, ND: not detected due to the absence of patient in a column. }\end{array}$} \\
\hline
\end{tabular}

Table 2. Comparison of thyrotropin-releasing hormone test parameters of the infants in groups 1 and 2

\begin{tabular}{|c|c|c|c|c|c|c|c|c|c|c|c|}
\hline & $\begin{array}{l}\text { Recall } \\
\text { TSH } \\
\text { (mlU/L) }\end{array}$ & $\begin{array}{l}\text { Recall } \\
\mathrm{fT}_{4} \\
\text { (ng/mL) }\end{array}$ & $\begin{array}{l}\text { *Trigger } \\
\text { TSH } \\
\text { (mIU/L) }\end{array}$ & $\begin{array}{l}\text { Basal } \\
\text { TSH } \\
\text { (mIU/L) }\end{array}$ & $\begin{array}{l}\text { Basal } \mathrm{fT}_{4} \\
\text { (ng/mL) }\end{array}$ & $\begin{array}{l}\text { Basal fT } 4 / \\
\text { TSH }\end{array}$ & $\begin{array}{l}\text { TSH } \\
15^{\text {th }} \text { min } \\
\text { (mIU/L) }\end{array}$ & $\begin{array}{l}\text { TSH } \\
45^{\text {th }} \text { min } \\
(\mathrm{mIU} / \mathrm{L})\end{array}$ & $\begin{array}{l}\text { TSH } \\
60^{\text {th }} \text { min } \\
(\mathrm{mIU} / \mathrm{L})\end{array}$ & $\begin{array}{l}{ }^{* *} \text { Delta } \\
\text { TSH } \\
\text { (mIU/L) }\end{array}$ & $\begin{array}{l}\text { Peak } \\
\text { TSH } \\
\text { (mIU/L) }\end{array}$ \\
\hline $\begin{array}{l}\text { Group } 1 \\
(n=4)\end{array}$ & $\begin{array}{l}6.3 \\
(6-8.9)\end{array}$ & $\begin{array}{l}1.5 \\
(0.9-1.7)\end{array}$ & \begin{tabular}{|l}
7.8 \\
$(6.1-9.6)$
\end{tabular} & $\begin{array}{l}4.4 \\
(2.9-6.8)\end{array}$ & $\begin{array}{l}1.4 \\
(1.3-1.6)\end{array}$ & $\begin{array}{l}5.3 \\
(3.9-7.1)\end{array}$ & $\begin{array}{l}29.7 \\
(24.2-33.5)\end{array}$ & $\begin{array}{l}20.5 \\
(18.2-27.2)\end{array}$ & $\begin{array}{l}24.1 \\
(18.5-27.2)\end{array}$ & $21.9 \pm 11.1$ & $26.7 \pm 9.4$ \\
\hline $\begin{array}{l}\text { Group } 2 \\
(n=16)\end{array}$ & $\begin{array}{l}8.1 \\
(7-16.3)\end{array}$ & $\begin{array}{l}1.4 \\
(1-1.6)\end{array}$ & \begin{tabular}{|l|}
7.4 \\
$(6.2-9.8)$
\end{tabular} & \begin{tabular}{|l|}
7.5 \\
$(5.3-9.8)$
\end{tabular} & \begin{tabular}{|l|}
1.4 \\
$(1.2-1.6)$
\end{tabular} & $\begin{array}{l}5 \\
(4.3-7.8)\end{array}$ & $\begin{array}{l}46 \\
(42.9-55.2)\end{array}$ & $\begin{array}{l}44.4 \\
(36.7-52.2)\end{array}$ & \begin{tabular}{|l}
33 \\
$(29.5-45.2)$
\end{tabular} & $42.8 \pm 7.8$ & $50.8 \pm 9.8$ \\
\hline$p$ & 0.18 & 0.59 & 0.85 & 0.53 & 0.07 & 0.69 & 0.003 & 0.01 & 0.007 & 0.002 & 0.003 \\
\hline \multicolumn{12}{|c|}{$\begin{array}{l}\text { *Thyroid-stimulating hormone level that prompted the thyrotropin-releasing hormone test, } \\
\text { **Difference between basal and peak thyroid-stimulating hormone levels, }\end{array}$} \\
\hline
\end{tabular}


Altıncık A et al.

Thyrotropin-Releasing Hormone Test in Infants

Table 3. Clinical and laboratory data of the patients who could discontinue and those who could not discontinue treatment

\begin{tabular}{|c|c|c|c|}
\hline & $\begin{array}{l}\text { Patients who could discontinue } \\
\text { treatment } \\
(\mathrm{n}=4)\end{array}$ & $\begin{array}{l}\text { Patients who had to continue treatment } \\
(n=15)\end{array}$ & p-value \\
\hline Recall TSH (mIU/L) & $9.1(6.5-16.2)$ & $7.5(6.3-10.1)$ & 0.52 \\
\hline Recall $\mathrm{fT}_{4}(\mathrm{ng} / \mathrm{mL})$ & $1.5(1.1-1.7)$ & $1.5(1.1-1.7)$ & 0.76 \\
\hline *Trigger TSH (mIU/L) & $9.6(6.9-16.2)$ & $7.0(6.2-9.1)$ & 0.23 \\
\hline${ }^{* *} \mathrm{fT}_{4} / \mathrm{TSH}$ ratio & $7.5(4.4-9.2)$ & $4.9(4.2-6.2)$ & 0.31 \\
\hline Basal TSH (mIU/L) & $5.0(3.9-5.8)$ & $7.6(5.3-9.8)$ & 0.051 \\
\hline Basal $\mathrm{fT}_{4}(\mathrm{ng} / \mathrm{mL})$ & $1.3(1.2-1.4)$ & $1.5(1.2-1.6)$ & 0.37 \\
\hline Peak TSH (mIU/mL) & $37.8(28.4-49.4)$ & $46.3(41.4-60.0)$ & 0.19 \\
\hline${ }^{* * *}$ Delta TSH (mIU/L) & $32.2(24.4-44.2)$ & $39.0(35.2-50.5)$ & 0.23 \\
\hline$\S \mathrm{L}$-thyroxine dose ( $\mu \mathrm{g} / \mathrm{kg} /$ day) & $4.5(1.6-7.5)$ & $2.4(1.8-3.7)$ & 0.07 \\
\hline Age at last visit (years) & $3.6(2.4-6.4)$ & $3.8(3.3-4.5)$ & 0.25 \\
\hline${ }^{¥}$ Follow-up duration (years) & $3(2.1-3.4)$ & $3.5(2.5-3.8)$ & 0.31 \\
\hline TSH at last visit (mIU/L) & $2.1(1.6-2.8)$ & $3.2(2.1-5.1)$ & 0.11 \\
\hline $\mathrm{fT}_{4}$ at last visit $(\mathrm{ng} / \mathrm{mL})$ & $1.4(1.1-3.9)$ & $1.4(1.2-1.5)$ & 0.94 \\
\hline \multicolumn{4}{|c|}{ 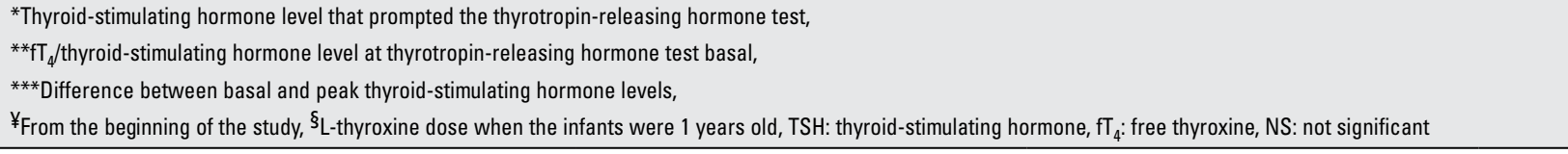 } \\
\hline
\end{tabular}

The authors concluded that infants with elevated TSH levels at neonatal screening are at risk of the development of $\mathrm{SH}$ in early childhood. However, this study did not report any information on the differences in the outcome of cases with normal or exaggerated responses to the TRH test. In our study, treatment could be discontinued in only two of the 16 infants with exaggerated TRH test results. Both of these infants were younger than 3 years and discontinuation had never been tried. In the remaining 12 infants, therapy could not be discontinued or had to be restarted.

A longitudinal evaluation of 44 of the 56 infants in Calaciura et al's study was reported later $(10,11)$. Twentyeight of these $44(63.6 \%)$ children had SH at early childhood (2-3 years old) and in 19 of these 28 (67.8\%) children, serum TSH levels persisted elevated at the evaluation between 4-6 years old. When thyroid functions were evaluated at a prepubertal age (a mean age of 8 years), high TSH levels were found to persist in 14 of 19 children $(50 \%$ of the children with $\mathrm{SH}$ at early age). Morphological abnormalities of the thyroid gland were frequent in these children. None of the children developed overt hypothyroidism in this study. However, mild hypothyroidism at prepubertal ages was observed in $22 \%$ of the children whose recall TSH was less than $5.0 \mathrm{mU} / \mathrm{L}$ in the newborn period and in $43 \%$ of children whose recall TSH was in the range of 5.0-12.0 $\mathrm{mU} / \mathrm{L}$.

In our study, one infant did not receive treatment due to normal TSH and $\mathrm{fT}_{4}$ levels at the TRH test. Treatment could be discontinued in 4 of the 20 infants and TSH levels were normal during the follow-up period of $2.0 \pm 1.7$ years. In conclusion, in five of the 20 infants with high TSH levels at recall examination, TSH levels were normalized.

$\mathrm{SH}$ has been associated with heart diseases and dyslipidemia in adults $(12,13)$. Progression to overt hypothyroidism is reported to be higher in adolescents (14). Very few data exist regarding the long-term outcome in newborns and infants with idiopathic $\mathrm{SH}$ without any underlying disease. In these reports, normalization of TSH varied between 39 and $73.6 \%$ and $25-58.7 \%$ of the patients remained $\mathrm{SH}$ during an observation period of 2-5 years. An increased TSH levels (>10 mIU/L) with normal $\mathrm{fT}_{4}$ were determined in $2-24.9 \%$ of the patients. Overt hypothyroidism developed in $0.03-13.5 \%$ of the children. Possible predictive factors for the development of hypothyroidism were initial TSH level $>7.5 \mathrm{mIU} / \mathrm{L}$ and female gender $(15,16,17)$. In our study, the clinical and laboratory data of the patients in whom treatment could be discontinued were not significantly different from those of the patients who had to continue treatment. Hence, there were no possible predictive factors to decide the discontinuation of treatment.

Daliva et al (18) followed-up fourteen infants with $\mathrm{SH}$ who were recalled from screening test. Six infants underwent $\mathrm{TRH}$ testing and had an exaggerated response. All infants were treated with L-thyroxine, and treatment was discontinued in all except one when the infants were 3 years old. Ten children had abnormal thyroid function tests 
on retesting off therapy and L-thyroxine was restarted. Three children had normal retest thyroid function and underwent a TRH test. Of these, 2 children had exaggerated response and L-thyroxine was restarted. TSH levels were normalized in only one child. All of the children with an exaggerated $\mathrm{TRH}$ response had to restart therapy due to persistently elevated TSH levels. In our study, L-thyroxine was restarted to three (two boys, one girl) of the 7 infants in whom the treatment was discontinued; however, overt hypothyroidism did not develop in these infants during the follow-up period without medication.

The major concern in the infants with $\mathrm{SH}$ is whether this situation has an effect on the infant's growth and mental development or not. In studies which have evaluated the natural course of idiopathic $\mathrm{SH}$ in children who received no treatment, no effects in height growth and BMI were found throughout the observation period (16). Also, no differences in height and $\mathrm{BMI}$ between treated and untreated children with SH were reported (19). We compared the auxological data of the infants with normal and exaggerated $\mathrm{TRH}$ test response at the last clinic visit and found no significant differences between the groups. However, it has to be considered that all of the infants in our study had received treatment.

There is limited data regarding the effect of thyroxine therapy on neurocognitive function in children with $\mathrm{SH}$. It is reported that these children have difficulties in focusing their attention and controlling their instinctive responses. Some studies showed that replacement therapy did not have an impact on neuropsychological function. However, duration of L-thyroxine treatment and number of subjects in these studies were very limited $(20,21)$. We routinely do not perform neurodevelopmental or intelligence tests in infants with $\mathrm{SH}$ in our department. None of the parents had reported any complaints such as attention disorder in our study group.

Environmental factors such as iodine deficiency, maternal autoimmune factors, and genetic factors like thyroperoxidase (TPO) and TSH receptor (TSH-R) gene mutations can cause $\mathrm{SH}$. Our study design was retrospective and because genetic tests were not performed routinely in these patients, genetic data were absent. Also, although Turkey is an iodine-deficient area, urinary iodine measurements were not performed in our study subjects. These were the limitations of our study.

In conclusion, L-thyroxine treatment could be discontinued in only 2 of the 16 infants with exaggerated $\mathrm{TRH}$ test response in this study. Treatment was not restarted in two of the 4 infants with normal TRH test results. $\mathrm{TRH}$ response to $\mathrm{TRH}$ stimulation may be a useful diagnostic test for the evaluation of these infants.

\section{References}

1. Léger J, Olivieri $A$, Donaldson $M$, Torresani $T$, Krude $H$, van Vliet G, Polak M, Butler G; ESPE-PES-SLEP-JSPEAPEG-APPES-ISPAE; Congenital Hypothyroidism Consensus Conference Group. European Society for Paediatric Endocrinology Consensus Guidelines on Screening, Diagnosis and Management of Congenital Hypothyroidism. J Clin Endocrinol Metab2014;99:363-384. Epub 2014 Jan 21

2. Miki K, Nose O, Miyai K, Yabucuchi H, Harada T. Transient infantile hyperthyrotrophinaemia. Arch Dis Child 1989;64:1177-1182.

3. Chen XX, Qin YF, Zhou XL, Yang RL, Shi $Y H$, Mao HQ, Qu YP, Wang $X$, Zhao ZY. Diagnosis and treatment of subclinical hypothyroidism detected by neonatal screening. World $\mathrm{J}$ Pediatr 2011:4:350-354. Epub 2011 Jun 1

4. Köhler B, Schnabel D, Biebermann H, Gruters A. Transient congenital hypothyroidism and hyperthyrotropinemia: normal thyroid function and physical development at the ages of 6-14 years. J Clin Endocrinol Metal 1996;81:1563-1567.

5. Dilli D, Özbaş S, Acıcan D, Yamak N, Ertek M, Dilmen U. Establishment and development of a natiol newborn screening programme for congenital hypothyroidism in Turkey. J Clin Res Pediatr Endocrinol 2013;5:73-79.

6. Zung A, Tenenbaum-Rakover Y, Barkan S, Hanukoglu A, Hershkovitz E, Pinhas-Hamiel O, Bistritzer T, Zadik Z. Neonatal hyperthyrotropinemia: population characteristics, diagnosis, management and outcome after cessation of therapy. Clin Endocrinol (Oxf) 2010;72:264-271. Epub 2009 May 18

7. Brook CGD, Brown RS. Test and normal values in pediatric endocrinology. In: Brook CGD, Brown RS (eds). Clinical Handbook of Pediatric Endocrinology: Massachusetts, 2008;221-222.

8. Rapaport R, Sills I, Patel U, Oppenheimer E, Skuza K, Horlick M, Goldstein S, Dimartino J, Saenger P. Thyrotropin-releasing hormone stimulation tests in infants. J Clin Endocrinol Metal 1993;77:889-894.

9. Kurtoglu S, Covut IE, Kendirci M, Uzum K, Durak AC, Kiris A. Normal thyroid volume of children in Turkey: Pilot study in Kayseri province. IDD Newsletter 1995;11:41-42.

10. Calaciura F, Motta RM, Miscio G, Fichera G, Leonardi D, Carta A, Trischitta V, Tassi V, Sava L, Vigneri R. Subclinical hypothyroidism in early childhood: a frequent outcome of transient neonatal hyperthyrotropinemia. J Clin Endocrinol Metab 2002;87:3209-3214.

11. Leonardi D, Polizzotti N, Carta A, Gelsomino R, Sava L, Vigneri R, Calaciura F. Longitudinal study of thyroid function in children with mild hyperthyrotropinemia at neonatal screening for congenital hypothyroidism. J Clin Endocrinol Metab 2008;93:2679-2685. Epub 2008 Apr 29

12. Nanchen D, Gussekloo J, Westendorp RG, Stott DJ, Jukema JW, Trompet S, Ford I, Welsh P, Sattar N, Macfarlane PW, Mooijaart SP, Rodondi N, de Craen AJ; PROSPER Group. Subclinical Subclinical thyroid dysfunction and the risk of heart failure in older persons at high cardiovascular risk. J Clin Endocrinol Metab 2012;97:852-861. Epub 2012 Jan 11

13. Rodondi N, den Elzen WP, Bauer DC, Cappola AR, Razvi S, Walsh JP, Asvold BO, lervasi G, Imaizumi M, Collet TH, Bremner A, Maisonneuve P, Sgarbi JA, Khaw KT, Vanderpump MP, Newman AB, Cornuz J, Franklyn JA, Westendorp RG, Vittinghoff E, Gussekloo J; Thyroid Studies Collaboration. Subclinical hypotyroidism and the risk of coronary heart disease and mortality. JAMA 2010;304:1365-1374. 
Altıncık $A$ et al

Thyrotropin-Releasing Hormone Test in Infants

14. Biondi B, Cooper DS. The clinical significance of subclinical thyroid dysfunction. Endoc Rev 2008;29:76-131. Epub 2007 Nov 8

15. Lazar L, Frumkin RB, Battat $E$, Lebenthal $Y$, Philip $M$, Meyerovitch J. Natural history of thyroid function tests over 5 years in a large pediatric cohort. J Clin Endocrinol Metab 2009;94:1678-1682. Epub 2009 Feb 24

16. Wasniewska M, Salerno M, Cassio A, Corrias A, Aversa T, Zirilli G, Capalbo D, Bal M, Mussa A, De Luca F. Prospective evaluation of the natural course of idiopathic subclinical hypothyroidism in childhood and adolescence. Eur J Endocrinol 2009;160:417-421. Epub 2008 Dec 12

17. Radetti G, Maselli M, Buzi F, Corrias A, Mussa A, Cambiaso P, Saalerno M, Cappa M, Baiocchi M, Gastaldi R, Minerba L, Loche S. The natural history of the normal/mild elevated TSH serum levels in children and adolescents with Hashimoto's thyroiditis and isolated hypertrotropinaemia: a 3-year followup. Clin Endocrinol (Oxf) 2012;76:394-398.
18. Daliva AL, Linder B, DiMartino-Nardi J, Saenger P.Three-year follow-up borderline congenital hypothyroidism. J Pediatr 2000;136:53-56.

19. Wasniewska M, Corrias A, Aversa T, Valenzise M, Mussa A, De Martino L, Lombardo F, De Luca F, Saalerno M. Comparative evaulation of theraphy with $L$-thyroxine versus no treatment in children with idiopathic and mild subclinical hypothyroidism. Horm Res Paediatr 2012;77:376-381. Epub 2012 Jun 12

20. Aijaz NJ, Flahherty EM, Preston T, Bracken SS, Lane $\mathrm{AH}$, Wilson TA. Neurocognitive function in children with compansated hypothyroidism: lack of short term effects on or off thyroxine. BMC Endocr Disord 2006;6:2-5.

21. Ergür AT, Taner $Y$, Ata E, Melek E, Bakar EE, Sancak T. Neurocognitive functions in children and adolescents with subclinical hypothyroidism. J Clin Res Pediatr Endocrinol 2012;4:21-24 